\title{
Journal of Contemporary
}

\section{European Research}

Volume 16, Issue 2 (2020)

\section{A New Scramble for Eurafrica? Challenges for European Development Finance and Trade Policy after Brexit}

Mark Langan

Citation

Langan, M. (2020). 'A New Scramble for Eurafrica? Challenges for European Development Finance and Trade Policy after Brexit', Journal of Contemporary European Research 16 (2): 218-233. https://doi.org/10.30950/jcer.v16i2.1074

First published at: www.jcer.net 


\section{Abstract}

The British referendum on continued EU membership in 2016 was infused with Brexiteer discourse relating to a fairer UK relationship with African countries inside the Commonwealth. Prominent campaigners including Boris Johnson and Daniel Hannan regularly spoke of the EU's mercantilist trade and aid policies in sub-Saharan Africa as a means to underscore the supranational project's unsavoury relationship with Anglophone developing countries. Brexit, it was claimed, would usher in a new era whereby the UK Department for International Development (DFID) - and a resurgent UK Department for International Trade (DFIT) - would have the opportunity to offer humanitarian aid and free trade unencumbered by the cynicism of the European Commission. Recent policy papers from both DFID and DFIT, however, have made clear that the UK intends to replicate the Economic Partnership Agreements (EPAs) under negotiation between the European Commission and sub-regions of the African, Caribbean and Pacific (ACP) bloc. This is despite Brexiteer discourse about the EPAs' apparent pitfalls relating to non-tariff barriers and the import-flooding of African markets. Perhaps more worryingly, meanwhile, DFID and DFIT publications highlight the need for UK Development Finance Institutions (DFIs) - notably the CDC Group - to robustly compete with their EU counterparts, to gain better market share for UK businesses within emerging African markets. In this context, the article argues that Brexit will intensify a 'new scramble for Africa' and highlights emerging challenges for European development cooperation vis-à-vis normative pledges to sustainable development. Additionally, it considers possible African responses via reflection on the writings of Kwame Nkrumah regarding 'neo-colonialism'.

\section{Keywords}

Aid blending; Brexit; development finance; trade; neo-colonialism 


\section{INTRODUCTION}

The founding of the European project with the Treaty of Rome in 1957 was underpinned by Eurafrican sentiments regarding the need for a continuing 'Association' with then colonies in sub-Saharan Africa. European founding fathers, including Robert Schuman in the famous Schuman Declaration, insisted that the supranational project would have an 'essential task' to assist then African colonies with economic and social development (Martin 1982). Through a pan-European effort - involving trade and aid assistance African territories could realise the developmental benefits of a Eurafrican Association between the two continents. This Eurafrican ideology, embedded within the Treaty of Rome in terms of its Association clauses, was further underpinned by the twin concepts of economic interdependence and complementarity (ibid). Namely, that Europe's industrial might and technological advances were essential to the satisfaction of African needs in terms of importation of machinery and equipment. Meanwhile, Africa's raw material wealth was essential to the fuelling of European industry. The two blocs, joined together by geography, therefore had a common destiny as part of a Eurafrican arrangement, led of course by the European nation-states as part of a mission civiliatrice (Thorpe 2018).

This Eurafrican component at the heart of the European project met with significant resistance from African luminaries including Kwame Nkrumah, the first President of an independent Ghana; his Guinean counterpart, Sekou Touré; as well as leading intellectuals including Frantz Fanon (Pasture 2018). In their respective texts, these figures warned against a 'collective colonialism' in which predominantly French colonial privileges would be extended to other European states upon their membership of the supranational European Economic Community (EEC) (Nkrumah 1965; see also XX in this issue). In exchange for contributing to the European Development Fund (EDF) geared towards infrastructural projects in the African colonies (useful for resource extraction), states such as West Germany would gain privileged trading access to colonies hitherto reserved to the French metropole. Nkrumah, in particular, warned against the neo-colonial logic of Association between the EEC and African territories - even upon their legal independence - due to the marriage of aid to disadvantageous market-opening (Martin 1982). Nkrumah warned that in such circumstances African states would remain dependent upon European largesse while failing to diversify away from colonial patterns of raw material extraction and manufactured goods importation. Moreover, he warned that aid would corrupt pliable African elites who themselves might benefit from the continuation of asymmetric economic ties between the constituent continents of Eurafrica. His warnings were echoed by Touré (1962) who stated that Association would 'foreclose the possibility of industrialisation in advance' and would condemn African countries to remain as mere 'hewers of wood and drawers of water'. Fanon (1961), meanwhile, warned in a similar vein about the dangers of African elite collaboration with former colonial powers, warning against the rise of authoritarian leaders who would betray the aspirations of liberation nationalism.

In this historical context, European fragmentation brought about by the UK's intended departure from the European Union (EU) might - at face value - be deemed a 'win' for African countries in the sense of diminishing the opportunities for a 'collective colonialism' driven by Eurafrican ideology. Certain African governments have in fact seized upon Brexit to challenge controversial EU trade liberalisation agendas embodied in the Economic Partnership Agreements (EPAs) being pursued under the EU's Cotonou treaty with African, Caribbean and Pacific (ACP) states. Tanzania, most notably, has queried why it should undergo stringent tariff dismantling under an EPA in return for continued access to EU markets especially now that one of its chief markets, the UK, will no longer be a party to the arrangement (Mold 2018; Krapohl and Van Huut 2019). Certain African civil society commentators - as well as European counterparts - have therefore hailed Brexit as an opportunity for African states to challenge unfair economic and trade arrangements and to 'balance' the UK against the remaining EU-27 in ensuing negotiations (Mold 2018). Interestingly, this line of argument has even been advanced by European populists in their 
attempts to, first, bring about Brexit and, second, to legitimise its implementation. Notably, a recent report by the Europe of Freedom and Direct Democracy (EFDD) grouping in the European Parliament has hailed Brexit as a blow to the neo-colonial prerogatives of Brussels (Finch and Crois 2018). Brexit, they insist, will bring about a truly free trade stance from the British government, which will not seek to replicate damaging EU protectionism against African imports, as witnessed under the controversial Common Agricultural Policy (CAP), to name but one instrument. This article, however, seeks to illustrate why Brexit - and this moment of apparent European fragmentation - will not necessarily - or even likely - result in fairer forms of trade and aid arrangements for African countries. In fact, Brexit will intensify a new 'scramble for Eurafrica'. Namely, a situation in which Britain and the EU-27 compete for their zone of influence in emerging African markets, particularly in terms of their respective development finance institutions (DFIs). With Brexit, the dangers of what Nkrumah termed 'neo-colonialism' will not dissipate. Instead the symptoms of neo-colonialism will be even more apparent, unless African actors exhibit greater agency to bring about pan-African responses to the interventions of foreign European nations.

The discussion is structured as follows. The first section explores the Eurafrican underpinnings of the EU as surpranational project and examines how certain African and European commentators have hailed Brexit as a potential victory for greater degrees of African sovereignty in trade and aid dealings with European powers. The second section then poses a rejoinder to such hopes in terms of ensuing UK trade and aid policies in a post-Brexit era. Rather than bring about a more egalitarian form of Afro-European relations, Brexit will entrench and intensify existing UK ambition for 'Empire 2.0' with development 'aid' being geared towards conclusion of controversial free trade deals, and the financial penetration of emerging African markets. Moreover, it will intensify existing European rivalries regarding their DFI investments, including those pursued by the EU itself in terms of the EU-Africa Infrastructure Trust Fund (EUITF), the EU External Investment Plan, and the recent Africa-Europe Alliance for Sustainable Investment and Jobs. The article then concludes with a consideration of avenues for greater African agency - in response to the dangers of Brexit for the continent amidst an intensified Eurafrican scramble for its markets and resources.

\section{EURAFRICAN IDEOLOGY AND THE ‘COLLECTIVE COLONIALISM’ OF THE SUPRANATIONAL PROJECT}

The Treaty of Rome in 1957 incorporated then African 'overseas territories' into an Association with the EEC without consultation with African political elites, in the context of colonialism (Brown 2002). Association granted the founding EEC members preferential trade access to the (predominantly) French colonies in sub-Saharan Africa in return for their contribution to a collective aid mechanism - the EDF (Brown 2002). The onset of Association, meanwhile, was not an accident of the negotiations in Rome alone. Rather it reflected a longer-standing Eurafrican ideology present within European supranational thinking as far back as the 1930s, and reflected strongly in the Schuman Declaration of 1953 (Thorpe 2018; Pasture 2018). Eurafrican ideology held - and today, as articulated by figures such as recent President Nicolas Sarkozy, holds - that the two continents share a common destiny based upon an inevitable economic interdependence and trade complementarity. Resource-rich Africa is essential to European industry; and European industry and commerce is essential to the economic and social development of the African continent (Hanssen and Jonsson 2014). A 'win-win' Eurafrican alliance was therefore envisaged which would unite European countries and African territories in the context of an ongoing colonialism, and in the context of European ambition vis-à-vis the Cold War superpowers, the USA and USSR.

Crucially, this Eurafrican component embedded in the foundations of the EEC was met with open hostility from a number of African luminaries, most notably Kwame Nkrumah (1965). 
As an increasing number of African states followed Ghana's example by gaining formal juridical independence, Nkrumah warned that genuine empirical sovereignty might be thwarted within neo-colonial forms of Eurafrican Association. Namely, that the EEC would utilise its aid mechanisms to cajole African leaders to acquiesce to the continuation of asymmetric, colonial-style forms of raw material extraction and manufactured goods importation (ibid). Aid monies, economic pressure, as well as at times, military intervention, would be utilised by European powers to ensure the compliance of newly 'independent' African nations within neo-colonial forms of economic dominance and political tutelage. Nkrumah - alongside Sekou Touré (1962) and Frantz Fanon (1961) therefore warned against premature economic liberalisation vis-à-vis European nations within any form of Association. This would, for African socialist thinkers, foreclose the possibility of economic diversification and industrialisation away from colonial patterns of trade, since it would allow unfettered importation of European goods to the decimation of emerging domestic sectors (such as cotton-textiles manufacturing).

Despite these warnings, however, Association continued to operate even after the advent of the formal independence of many African countries in the late 1950s and 1960s. Notably, the Yaoundé Conventions (1963-1975) were established between the EEC and the Associated African States and Madagascar (AASM) in large part due to the promise of funding for infrastructural development under the EDF, as well as preferential trade access to European markets (Brown 2002). Interestingly, however, the Yaoundé Conventions, while including a new discourse of 'sovereign equality', also included a discourse of the need for 'reciprocal' trade liberalisation - namely that AASM countries should avoid protectionist tariffs upon EEC wares. This confirmed the existing fears of African socialists, such as Nkrumah, that a noxious marriage of aid and trade meant that African countries would acquiesce to disadvantageous free trade arrangements and would do away with protectionist policies vital to economic diversification and industrialisation (Langan 2018).

Nevertheless, this overarching commitment to trade reciprocity within Eurafrican Association was challenged under the first Lomé Convention (1975-1980) which - in response to the agitation of 'Third World' countries under the New International Economic Order (NIEO) - promised for the first time a commitment to 'non-reciprocal trade' (Gruhn 1976). This ostensibly meant that African Associates (now within the expanded African, Caribbean and Pacific [ACP] bloc upon the accession of Britain and its former colonies to Eurafrican arrangements) would be allowed policy space to utilise protectionist tariffs and quotas to protect their infant industry. In practice, however, the onset of the Washington Consensus and structural adjustment programmes (SAPs) - supported by the European Commission in terms of EDF conditionalities - meant that African states under Lomé II, III and IV (1980-2000) did undergo substantial tariff dismantling as part of SAP recommendations for open trade policies (Mailafia 1997). This coincided with the privatisation of infant industry, including Kenyan textiles parastatals with the loss of 70,000 jobs, and de-regulation with regards to policies including national minimum wages (Langan 2018).

Furthermore, in the most recent phase of Eurafrican Association under the ACP-EU Cotonou Agreement (2000-2020), the commitment to reciprocal trade liberalisation has been enshrined in treaty and has been actively pursued since 2000 in terms of regional Economic Partnership Agreements (EPAs). The EPAs have been promoted by the European Commission on the grounds of promoting ACP countries 'smooth and gradual integration' into global markets through phased liberalisation. A majority of ACP product lines will undergo tariff dismantling, yet up to $20 \%$ of their products may possibly be included within 'sensitive goods baskets' (European Commission 2016). This apparently will enable ACP states to protect sectors which are insufficiently robust to compete within open markets, until such times as they gain competitive muscle. Moreover, the EPAs will ensure ACP countries' ongoing access to European consumers, albeit protectionist measures such as the Common Agricultural Policy (CAP) remain in place (as do EU tariffs which impose 
prohibitive costs upon processed goods from ACP nations such as confectionary). ${ }^{1}$ The EPAs have therefore been condemned by many civil society groups, and even Members of the European Parliament (2016), on the basis that they impose premature liberalisation to the detriment of local industry that will be impacted by import flooding of additional EU wares. Namely, the sensitive goods basket is viewed as inadequate to protect manufacturing industries since the majority of products selected will inevitably be agricultural commodities with ACP states' eye to ensuring food security (Matambalya 2009). Additionally, the EPAs will not resolve non-tariff barriers (NTBs) which continue to hinder ACP producers' meaningful access to European marketplaces, such as strict phytosanitary and hygiene requirements. ACP states are therefore seen to acquiesce to EPAs in no small part due to promised 'Aid for Trade' monies under the EDF, despite the fact that such agreements 'lock in' developing countries into colonial-style patterns of raw material production and manufactured importation (Langan and Scott 2014).

It is in this context that certain commentators, both in Europe and in Africa, have viewed Brexit as a potential boost to African agency in dealings with the EU, and the UK itself. From a critical standpoint concerned with 'collective colonialism' under Eurafrican Association, it might at first appear a gain for African countries that there is a moment of European fragmentation as represented in the UK's decision to leave the EU. Governments, including that of Tanzania, have seized upon Brexit to argue that the EU EPAs need to be renegotiated in their entirety. Others, meanwhile, have expressed hope that the UK newly imbued with an independent trade competency - would be able and willing to conclude a more progressive form of trade deals with African nations, particularly those of the Anglophone Commonwealth (see for example Traidcraft 2017). Indeed, this line of argument was expressed by Brexiteer politicians themselves before and during the referendum campaign of June 2016 in their promises to end the trade 'betrayal' of Anglophone former colonies (Murray-Evans 2016). Prominent UK civil society groups while not necessarily Eurosceptics themselves - have thus called upon Westminster elites to use Brexit as an opportunity to reform trade policy vis-à-vis African economic development. In particular, there have been calls for the UK to lead by example by eliminating discriminatory tariffs imposed upon processed goods from African origins, and by refraining from imposition of stringent liberalisation conditions upon developing economies (Traidcraft 2017). Additionally, there have been calls for UK aid monies to be used explicitly for the promotion of small and medium sized enterprises (SMEs) in subSaharan Africa since these entities are deemed most capable of achieving genuine forms of poverty alleviation within more vulnerable communities. Despite this apparent optimism, however, the prospects of a 'break' in Eurafrican relations of dependency appear unlikely. Rather, it would seem that Brexit will intensify a 'new scramble' between the EU-27 and the UK for emerging African markets as the next section now examines.

\section{EMPIRE 2.0 AND A 'NEW SCRAMBLE' FOR EMERGING MARKETS IN AFRICA?}

According to Brexiteer discourse and the UK government's stated policy, British trade and aid policy will gain a much greater degree of autonomy in the post-Brexit period. Notably, the formation of a new Department for International Trade currently led by Dr Liam Fox underscores the UK's intention to forge new trade arrangements based upon a renewed competency in this area. Moreover, UK officials have been keen to emphasise that the UK will play a progressive role in efforts for sustainable development through such policy instruments (Price 2016; Henokl 2018). While emphasising that British interests will come to the fore in post-Brexit trade negotiations - and aid arrangements too - nevertheless there is an explicit 'pro-poor' discourse within the communications of the UK government with regards to the exercise of British policy making. In part this reflects a desire to fulfil rhetorical commitments made during the referendum campaign about the UK's desire (post-Brexit) to offer a fairer deal to developing countries. Additionally, it in part represents a British (or rather English) imperial nostalgia for the Commonwealth nations, and a desire 
to forge new relationships with former colonies in the Anglosphere. Central to these propoor narratives, meanwhile, is a focus on economic growth and private sector development (PSD) as the key ingredient for poverty reduction. The Department for International Trade (DFIT)'s policy communication - Preparing for our Future UK Trade Policy - usefully illustrates this pro-poor growth narrative:

The UK government has a long-standing commitment to support developing countries to reduce poverty through trade. The government will continue to deliver improved support in the future by helping those developing countries break down the barriers to trade. This will help them to continue to benefit from trade by growing their economies, increasing incomes and reducing poverty. Helping to build developing countries' prosperity creates the conditions that allow commerce to flourish and in doing so, opens up opportunities for UK business in future markets (DFIT 2017).

Interestingly the UK's Department for International Development (DFID) is in full alignment with this pro-poor growth discourse, and, unusually, DFID ministers have embarked on 'trade' missions to sub-Saharan Africa to complement the efforts of the newly formed trade ministry itself. The DFID (2017) Economic Development Strategy, for instance, clearly states that:

We are focusing investment in job creation across manufacturing, infrastructure and commercial agriculture to provide strong foundations for inclusive growth in the developing world. Communities and businesses need electricity, roads, dynamic cities and for rural areas to be connected to markets. We need to transform agriculture to feed and nourish rising populations and enable millions of smallholder farmers to tap into global value chains. We need to enable countries to look to future dynamic sectors of the global economy and use new technologies.

An intertwining of trade and 'development' is therefore apparent, both in terms of discourse and in terms of institutional alliances between DFIT and its DFID counterpart.

Again, however, UK ministers have repeatedly asserted that British economic and geopolitical interests will come to the fore in the post-Brexit period of African ties. And in no small measure this rhetorical element seeks to bolster continued public support for government aid-spending and for the prospect of an independent UK trade competency. Theresa May during her tenure as Prime Minister was particularly prominent with regards to the articulation of this discursive theme:

As prime minister of a trading nation whose success depends on global markets, I want to see strong African economies that British companies can do business with in a free and fair fashion," May will say in Cape Town. "Whether through creating new customers for British exporters or opportunities for British investors, our integrated global economy means healthy African economies are good news for British people as well as African people (DFID 2018).

Under the premiership of Boris Johnson, this focus on UK interests continues, with the UKAfrica Investment Summit of January 2020 as a clear signal of British intent to 'turbocharge', in the words of current DFID Secretary of State, Alok Sharma, its dealings in the continent (Blomfield 2020). It is important to note, however, that this focus on British enlightened self-interest in dealings with African states in fact precedes the Brexit referendum and the current period of the May government. Indeed, this narrative of winwin engagement and self-interest found expression in the period of the David Cameron premiership. Then DFID minister, Justine Greening, expressed in 2013, for instance, that UK aid monies would be geared towards promoting responsible forms of investment in African economies, to the benefit of British business and poverty reduction in developing 
countries. Additionally, it was this minister who led the first DFID 'trade' delegation to the continent, in a visit to Tanzania (DFID 2013).

Furthermore, British ministers have emphasised that the EU's EPAs with African regional groupings such as the Southern African Development Community (SADC) will be replicated within the UK's own trade policy. DFIT made this commitment clear, alongside adjacent commitments to respect for the Everything But Arms (EBA) agreement currently offered by the EU to least developed countries (in terms of quota free and duty free access to European consumers):

The UK remains committed to ensuring developing countries can reduce poverty through trading opportunities. As we leave the EU, we will maintain current access for the world's LDCs to UK markets and aim to maintain the preferential access of other (non-LDC) developing countries. This means we will establish a UK unilateral trade preferences scheme to support economic and sustainable development in developing countries. This will include those countries currently benefitting from the EU's GSP, including beneficiaries of the EBA, standard GSP and GSP+ tiers. We will also seek to replicate existing EPAs (in line with other EU-third country FTAs) as we prepare to leave the EU (DFIT 2017).

Meanwhile, in August 2018, Prime Minister May announced that the UK had tentatively agreed with six African nations (Mozambique, South Africa, Botswana, Lesotho, Namibia and eSwatini) that the terms of the EU EPA will form the basis of a post-Brexit trading arrangement. This was hailed by the then premier as evidence of the clout of 'Global Britain' to secure win-win trade agreements (The Economist 2018). Hopes, therefore, for a British progressive alternative to EPAs - perhaps including a commitment to nonreciprocal trade patterns involving unilateral UK tariff dismantling - appear ill-founded.

Moreover, the UK's focus on the use of aid monies for bolstering African economies while also securing British trade and commercial interests raises significant concerns in terms of the achievement of stated poverty reduction goals. Namely it raises concerns of a 'new scramble' for Eurafrican markets between the UK and the remaining EU-27. Illustrative of such fears, a coalition of trade justice bodies collectively campaigned under the banner 'No to Empire 2.0' on the eve of the January 2020 UK-Africa Investment Summit, warning African leaders to beware British predatory investors (Global Justice Now 2020). Of paramount concern here, DFID has emphasised that UK aid monies will increasingly be channelled towards the CDC Group (formerly known as the Commonwealth Development Corporation) (Lightfoot et al 2017). This is a development finance institution (DFI) which was formerly wholly owned by the UK Treasury and now is a private entity in which DFID is the sole stakeholder. The function of the CDC Group is to 'leverage' capital into African economies by minimising risk associated with private sector investment. To date this has prioritised the privatisation of, and thereafter investment into, African energy assets such the Umeme electricity distribution network in Uganda. This Ugandan intervention lead to substantial profits for UK investors, combined to substantial fee increases for local utility users (Bracking 2009: 78). In 2007 alone, $\$ 750$ million was placed by CDC into energy assets via Actis, 'a fund management company owned by the bulk of the former senior staff of CDC'. (ibid: 76).

The CDC Group also provides capital as leverage for investment into agribusiness schemes in sub-Saharan Africa, often associated with accusations of agro-colonialism, labour rights abuses, environmental destruction and land grabbing (see for instance RIAO-RDC \& GRAIN 2015 and Carden 2020 on Feronia scandal). As well as dubious 'development' funding for elite private school chains, private healthcare facilities, as well as a Prosperity Fund to facilitate free trade access for British firms (Global Justice Now 2020). In the post-Brexit phase, the role of the CDC Group is also described as a means of ensuring the ongoing 
prominence of the City of London in terms of providing expertise and risk-mitigation visà-vis UK private investment into Africa. The UK government, meanwhile, has promised that Britain will invest an additional $£ 4$ billion into the continent in the wake of Brexit, indicating that the UK remains an important development actor, especially in Anglophone African countries such as Nigeria. As Kohnert (2018: 121) indicates, British FDI flows have already increased remarkably even prior to the recent phase of Brexit preparations. Perhaps unsurprisingly - and in alignment with the priorities of CDC Group to obtain 'revolving funds' (that is, profits) from investments - the majority of those sectors in receipt of British investment are found within the industrial and extractive industries:

The amount of UK investment in Africa, which more than doubled between 2005 and 2014 from GBP 20.8 billion to GBP 42.5 billion, was meant to be enhanced by Brexit. South Africa will most likely remain the largest recipient of UK FDI (Vines 2018: 122123). It already accounted for 29.8 per cent of total UK (outward) FDI in Africa in 2014 (Hardie 2016). Industry, mining, and financial services have been the main industrial sectors receiving British FDI, with the first two accounting for 54.4 per cent and 34.3 per cent of total UK FDI into Africa in 2014, respectively (Hardie cited in Kohnert 2018: 121).

In this context, Mawdsley (2015: 358) convincingly argues that UK private financial initiatives undertaken by the CDC Group in controversial sectors such as mining do not sufficiently take into consideration the 'pro-poor' gains in terms of core labour standards, anti-corruption and anti-tax evasion conditions, or in terms of minimising the risk of financialisation vis-à-vis risk contagion.

As illustrated by the aforementioned civil society ' $N o$ to Empire 2.0 ' campaign coinciding with the January 2020 UK-Africa Investment Summit, these concerns about the regressive consequences of UK aid monies under DFID-CDC schemes are exacerbated in the context of Brexit. Bracking (2009: 91) notes that even within the framework of EU development policy, there have been numerous historical tensions between the priorities of individual member states and their respective national DFIs (such as the UK CDC):

Tensions arose between and within the Anglophone, Francophone and Lusaphone (Portuguese-speaking) zones which came to be managed within the EU as it developed a 'competition' policy for aid projects, a collectivised market which nonetheless continues to privilege European companies and financiers relative to those outside.

Accordingly, Brexit represents a potential intensification of these existing European rivalries in Africa, especially in relation to the UK and its own DFI arm since it would be inevitably removed from EU oversight and alignment. Already there is concern that the UK intends to depart from EU regulations regarding asset stripping with regard to investor behaviour across Europe itself, with potential consequences too for UK DFI behaviour in overseas countries, including those of Africa (see Sweeney and Sydor 2020). In addition, CDC group will likely cease to be a member of the Association of European Development Finance Institutions (EDFI) after Brexit, a body which commits itself to ensuring that its various DFI members adhere to UN criteria on responsible investment for sustainable development. The EDFI (2011) 'Harmonized Exclusion List', for instance, sets out clear guidelines regarding the need for its members to avoid investments in activities leading to human exploitation and ecological destruction:

EDFI Members will not finance any activity, production, use, distribution, business or trade involving... Forced labor or child labor... Ozone depleting substances, PCB's (Polychlorinated Biphenyls) and other specific, hazardous pharmaceuticals, pesticides/herbicides or chemicals... wildlife or products regulated under the Convention on International Trade in Endangered Species or Wild Fauna and Flora 
(CITES)... Unsustainable fishing methods... cross border trade in waste and waste products... destruction of High Conservation Value areas... radioactive materials... pornography and/or prostitution... racist and/or anti-democratic material... [or businesses mainly involving] alcoholic beverages... tobacco... weapons... gambling...

Since EDFI membership aligns with either EU membership or membership of the European Free Trade Area (EMFTA), CDC will likely no longer belong or be beholden to that association's oversight with regard to its Exclusion List after Brexit. Similarly, Brexit will enable DFID and the CDC Group to intensify their operations in African extractive, industrial and financial sectors without the oversight of the European Parliament - which has played a substantial role in drawing public attention to the excesses of DFI activities in Africa (see for example, European Parliament censoring of the EIB in relation to the Glencore mining scandal in Democratic Republic of the Congo and Zambia in terms of alleged tax evasion).

Illustrative of the UK's increasing appetite for African investment opportunities in a postBrexit landscape, Lord Boateng - the chair of the UK's Africa Enterprise Challenge Fund (another British DFI) - has expressed the view that Brexit will unleash opportunities for enhanced UK involvement in African emerging markets through capital investments. Interestingly, he compared the UK position to that of Germany, which he said had already made much progress via its own national DFI activities. He explained that the UK was 'late to the party' and that:

we have a lot of catching up to do if we are to make the most of what is an historic opportunity to recast the relationship between Africa and the UK away from it being seen solely as a philanthropic exercise, a basket case suitable only for [oversees aid], to an opportunity that requires investment, that requires risk taking and support by government for British companies (BBC 2018).

And even in the event of a UK economic downturn after Brexit - and growing public reticence toward UK aid spending - this channelling of funds to DFI activities will likely continue to take place, since corporate profits enabled through DFI spending will in most cases offset initial 'aid' expenditures (Bracking 2009).

Worryingly, this likely intensification of UK DFI activities in relation to CDC is contextualised in terms of the EU's own emergent policy emphasis on so-called 'aid blending' - namely the marriage of public aid monies to DFI activities (Bilal 2019). EU-sponsored DFI activities undertaken in relation to the EIB itself; the EU-Africa Infrastructural Trust Fund (EAITF); and more recently the European External Investment Plan (EEIP) with the adjacent European Fund for Sustainable Development (EFSD); as well as the new Africa-Europe Alliance for Sustainable Investment and Jobs (AEASIJ) all point to the intensification of EU development finance and public-private partnerships as the modus operandi for the achievement of the UN SDGs in the post-2015 setting. Indeed, as Mawdsley (2015: 344) remarks in terms of broader donor community trends, we are currently witnessing that 'economic growth is being ideationally and institutionally reinstated as the central and prior condition for "development".

Moreover, these trends are being explicitly backed by European corporations with an interest in extractive and energy sectors (EU-27 outfits such as Areva and Total) and in lucrative services sectors (UK outfits such as HSBC). Corporate submissions to public consultations on the EU's New European Consensus, for instance, regularly emphasis the need for greater EU support to 'public private partnerships' (PPP) in Africa (European Commission 2019). Such PPPs are regularly understood in terms of aid blending initiatives geared towards large infrastructural projects (undertaken by European corporations with a view to profitability in sectors such as energy). This has paved the way for EU institutions, 
EU member states, and the UK CDC itself, to represent enhanced DFI activities as a boost for African growth and poverty alleviation. This is despite the fact that a plethora of civil society, parliamentary and African government reports have pointed to the oftentimes regressive impacts of DFI portfolio investments for workers' rights, social stability, and ecological integrity in sub-Saharan Africa. On the latter issue, Monbiot (2019) has recently pointed to the likelihood of UK industry taking advantage of more lenient rules on pollution in the event of Brexit vis-à-vis the EU-27, giving British companies a competitive advantage especially in 'dirty' processing activities in sub-Saharan Africa.

This leads to a further point - namely that there is a likelihood that Brexit will complicate progressive alliances within the non-governmental sector between like-minded groups who to date have worked collectively to hold DFI institutions to account on an intra-EU basis. CONCORD (2017), the confederation of European development NGOs, estimates, for instance, that UK NGOs will lose EURO 140 million each year as a result of no longer receiving grants from EU auspices. UK NGO participation in intra-EU bodies such as CONCORD itself may be brought into question, with serious consequences in terms of holding national DFIs (such as CDC Group) to account. Moreover, in terms of public opinion, Brexit jingoism, and the rise of right-wing populist political parties within EU member states, there is the danger that critiques of a 'new scramble for African resources' will find little traction with public sympathies (in relation to negative consequences for poorer citizens in sub-Saharan Africa). On the contrary, there is a danger that public opinion will sanctify such activities on the understanding that British (or EU-based) companies profit from investments and that such profits benefit their home European state. This coincides with a media environment, in the UK at least, which seems ideologically sympathetic to the pro-poor growth discourse invoked by Westminster politicians and CDC representations to justify and legitimate their oftentimes dubious 'development' interventions into African economies. In this context, it becomes imperative for African governments, civil society, and indeed pan-African institutions (namely the African Union and its agencies) to realise increased agency to hold DFI discourse - and tangible interventions in their economies - to account.

\section{AFRICAN AGENCY TO CONTEST A 'NEW SCRAMBLE’ FOR EURAFRICA?}

As the above discussion has made clear, Brexit will stimulate neo-colonial forms of trade, aid and investment relations between the UK and African countries - as the UK government seeks to use the opportunity to unleash DFIs from EU regulations and to pursue free trade deals lubricated by 'development' monies. The EU-27, meanwhile, have themselves already demonstrated a growing reliance on aid blending and DFI activities as an ostensible means of delivering aid revenues and achieving the UN SDGs. This confirms the fears of African socialists such as Nkrumah, Toure and Fanon, who all recognised the likelihood of European powers utilising economic and political advantages to perpetuate dependency and to maintain access to Africa's lucrative resources and markets.

The prospects of an intensification of neo-colonial relations between European (UK and EU27) countries and African states in the wake of Brexit leads naturally to a discussion of potential African responses. Commentators such as The Economist (2019) point to the opportunities of a new scramble for African economies, in this case taking into account the activities too of the BRIC nations (Brazil, Russia, India and China). In such interpretations, African countries will have greater opportunities to play competing powers off against one another, thereby leading to better outcomes for 'development'. Oftentimes, for example, commentators on Chinese entry into Africa point to some of the advantages accruing to African elites in nations such as Rwanda and Uganda, due to China's less stringent (or nonexistent) criteria regarding human rights. Moreover, countries such as Ghana have at times played competing commercial interests (notably in the oil) sector against one another, for 
instance, threatening to invite greater Chinese participation in the sector when displeased with the behaviour of US oil interests (under the Presidency of John Kufuor) (Langan 2018). In the situation of UK competition with EU-27 nations after Brexit, however, it does seem uncertain as to whether African countries individually will be able to take advantage of intra-European tensions to gain better trade terms, or aid packages, or in terms of DFI behaviours in association with aid blending. Notably here, African elites themselves often benefit from the marriage of aid to disadvantageous trade or investment behaviour on the part of European partners. Budget support, for instance, from either UK or EU-27 to the functioning of the national budget can have a dampening effect on African elites genuine empirical sovereignty to challenge the behaviour of entities such as the EIB or CDI, on the understanding that EU or UK aid support would be reduced, or lost, in the event of a breach with the donor in question (Langan 2015). Moreover, in terms of trade agreements, instruments such as Aid for Trade packages - for instance, the EU's Economic Partnership Agreement (EPADP) with West African countries in relation to a regional free trade pact with EU member states - can again have a diminishing effect upon African elites' political willingness to challenge their European partners' policy priorities (Langan and Scott 2014).

In the event of Brexit, moreover, the UK government has already signalled its unwillingness to alter the fundamental reciprocal trade premise of the EU's own EPAs (DFIT 2017). It would seem unlikely, therefore, that African nations acting individually would have much opportunity to meaningfully challenge predatory DFI behaviours in the situation where CDC is increasingly competing (and undercutting in terms of environmental and social policies) its counterparts in the EU member states, as well as the EIB itself. This is at the same time, as mentioned above, that NGO alliances between UK and EU-27 to hold DFIs accountable will likely fragment as British campaign groups no longer gravitate towards collective bodies such as EURODAD.

There is potential scope, however, following the rationale of African luminaries who originally diagnosed the dangers of Eurafrica, to utilise pan-African institutions (namely the African Union [AU]) to more effectively challenge the neo-colonial commercial and trade prerogatives of either the UK or the EU-27. Interestingly, the EU itself has already signalled a greater intention to focus its African policy onto the AU Commission, rather than onto the African, Caribbean and Pacific (ACP) Secretariat (Chadwick 2018). This is especially so as the EU currently seeks to conclude a successor to the ACP-EU Cotonou Agreement, with the EU signalling that although the ACP group will still exist as an entity, that it envisages a greater devolution of its trade and aid relations to the individual regions (with the AU taking the lead for Africa). In such circumstances, the AU Commission must take a greater lead in overseeing any post-Cotonou relationship with the EU-27 especially in terms of the EPAs, and by default with the UK (which under a Brexit scenario will likely replicate the premise of EPA reciprocal trade). What will be essential here is the ability of the AU Commission to work with the Commissions of the individual sub-regions in the continent, for example, the ECOWAS Commission, to effectively monitor the impacts of the (sub-regional) EPAs as they unfold. For example, in the West African EPA it will be important for ECOWAS and AU officials to challenge import flooding of EU merchandise into that marketplace and to push for the enactment of safeguard clauses (included in the text of the EPA) where import flooding threatens food security or vital African economic interests. It will also be incumbent upon AU officials to work with sub-regional economic communities (RECs) to ensure that promised Aid for Trade monies are actually disbursed by the European Commission, and to ensure that Brexit does not result in an aid deficit which might detract from the headline figure promised under the EPADP, for instance.

In the longer term, meanwhile, intra-African economic co-operation and trade via the auspices of $A U$ initiatives may augur well for weaning African countries from colonial patterns of dependency upon European (EU-27 and UK) markets. Already the AU is leading on the ambitious African Continental Free Trade Area (AfCFTA) plan which, if realised, would create the conditions for freer and smoother trade between $A U$ member states 
(Saygili et al 2018). The potential for stimulating intra-African trade and establishing economies of scale necessary for industrialisation and diversification away from colonial export patterns does lie within pan-African initiatives, as laid out by critics of Eurafrica back in the 1960s in the immediate period of decolonisation (Nkrumah 1965; Fanon 1961; Toure 1962). The AU Commission, meanwhile, working in liaison with global governance bodies such as the UN Development Programme (UNDP) and International Labour Organisation (ILO) would also be better positioned than individual African governments to draw up continental standards - and potential penalties - with regard to the ethical functioning of European DFIs and aid blending/PPP schemes within Africa. And again, through the creation of African-led and African-resourced DFIs themselves via the leadership of the AU Commission, African elites might in time do well to supplant foreign DFIs, including those of the EU-27 and UK given their dubious development records in the continent. However, AU officials should here beware the ambitions of the European Commission to utilise the AfCTA as an opportunity to realise a bi-continental Eurafrican free trade zone which would unite the sub-regional EPAs. Premature liberalisation towards the EU on a pan-African scale would retard diversification and encourage import flooding.

Finally, the $A U$ as an institution offers African elites the forum in which to reconstruct panAfrican narratives and discourse to counteract and confront Eurafrican imaginations of development. Nkrumah (1965) notably hailed pan-African ideology as a necessary corollary of a process of economic independence and of psychological self-confidence on the part of African citizenries. Through the rediscovery and reinvigoration of a radical panAfrican narrative - critical of foreign impositions and development plans as embodied in Eurafrican interventions - the AU could do well to give African countries the discursive wherewithal to articulate a different vision to that of the mercantilist and neo-colonial prerogatives of European powers, whether that articulated by the European Commission in the period of post-Cotonou negotiations, or by the UK government (and its DFIT and DFID arms) in the period of Brexit preparations. The importance of such a discursive shift was also convincingly detailed by Fanon (1961) in terms of Africa discovering a civilizational voice geared towards economic autonomy and political sovereignty, in contradistinction to the neo-colonial impetus of Eurafrica. Overall it is clear, therefore, that any meaningful response to Brexit and the 'new scramble for Eurafrica' must entail a much greater degree of unity than heretofore seen (or at least not seen since the negotiations for the original Lomé Conventions in which African, Caribbean and Pacific countries collectively won major concessions - albeit fleetingly - from the European Commission in the context of debates for the New International Economic Order). The AU Commission in Addis Ababa, working within its individual member states, could pose a necessary and powerful counterweight to that of its governing counterparts in London and Brussels.

\section{CONCLUSION}

Brexit will not augur an opportunity for African countries as per Brexiteer discourse in the 2016 referendum. Rather than enable African governments to take advantage of an apparent European fragmentation to rewrite terms of trade and aid (for example the EPAs), Brexit will in fact likely augur greater competition between the UK and the EU-27 in what can accurately be deemed a 'new scramble for Eurafrica'. Already the UK government via DFID and DFIT - has expressed clear intentions to replicate the EPAs. Moreover, UK aid agendas are being increasingly allied to commercial interests and conditionalities as part of government attempts to demonstrate to an increasingly reticent British public that aid monies are justifiable expenditure. In addition, there is clearly a neo-colonial appetite on the part of UK elites to utilise Brexit as an opportunity to unleash the 'potential' of British DFIs (notably the CDC Group), unrestrained by Brussels regulations and behavioural oversight (including that of the European Parliament which heretofore has held the EIB to account, and NGO alliances as embodied in EURODAD). The EU-27, meanwhile, with an increasing emphasis on aid blending and PPP, as well as an unwillingness to revisit 
the terms of EPAs in the post-Cotonou phase, will remain wedded to a trade and aid agenda that underserves (and in fact undermines) poverty reduction prerogatives in sub-Saharan Africa. Brexit does not therefore appear to offer progressive opportunities of any kind. In terms of overcoming Eurafrican inequalities, therefore, it becomes increasingly clear, that African elites must challenge European powers in terms of unfair trade deals and compromising aid arrangements, especially those which lubricate developmentally dubious DFI activities in extractive sectors, energy sectors, and services industries. Following the logic of Nkrumah (1965), it is apparent that the AU Commission is the most viable institution in terms of a leadership body capable of co-ordinating a pan-African response to the neo-colonial agenda of the UK government and the EU-27. Whether in terms of ambitions for the AfCFTA, or the potential oversight and regulation of foreign DFI activities, it is the $A U$ which might hold European governments and corporations to account in terms of the often negative consequences of their interventions for jobs, livelihoods, and ecological security in the continent. Furthermore, a reinvigoration of a pan-African radical discourse would do well to counter the Eurafrican ideology which lies at the heart of the neo-colonial agendas of the UK and the EU-27 in their trade and aid dealings with former colonies.

\section{AUTHOR DETAILS}

Dr. Mark Langan, The School of Geography, Politics and Sociology, Newcastle University, NE1 7RU, United Kingdom. Email: mark.langan@ncl.ac.uk

\section{ENDNOTES}

${ }^{1}$ See Ansorg and Haastrup (2016) for more discussion on the CAP in the context of Brexit.

\section{REFERENCES}

Ansorg, N. and Haastrup, T. (2016). 'Brexit beyond the UK's borders: what it means for Africa'. GIGA Focus Africa, No. 3, September 1-10. Berlin: GIGA.

BBC News (2018). 'Theresa May pledges Africa investment boost after Brexit'. BBC News, 28 ${ }^{\text {th }}$ August 2018. London: BBC News.

Bilal, S. (2019). 'Leveraging the next EU budget for sustainable development finance', ECDPM Discussion Paper, No. 243: 124. Maastricht: ECDPM.

Blomfield (2020). 'Post-Brexit Britain will “turbo-charge” trade relations with Africa, says Sharma', The Telegraph, 14 $4^{\text {th }}$ January 2020. London: The Telegraph.

Bracking, S. (2009). Money and Power: Great Predators in the Global Political Economy. London: Pluto Press.

Brown, W. (2002). The European Union and Africa: The Restructuring of North-South Relations. London: I.B. Tauris \& Co. Ltd.

Carden, D. (2020). 'For profit investments are not "development"', New Internationalist, $18^{\text {th }}$ January 2020. Northampton: New Internationalist.

Chadwick, V. (2018). 'What's at stake as EU, Africa, Caribbean, Pacific, negotiate new accord'. DEVEX, $1^{\text {st }}$ November 2018. Brussels: DEVEX.

Department for International Development (2013). Justine Greening: Supporting Trade in East Africa. London: DFID.

Department for International Development (2017). Economic Development Strategy. London: DFID. 
Department for International Development (2018). PM Takes Message on Investment in Africa to UN. London: DFID.

Department for International Trade (2017). Preparing for our Future UK Trade Policy. London: DFIT.

The Economist (2018). 'Doing the Brexit shimmy: Britain's belated charm offensive in Africa', The Economist, 30 ${ }^{\text {th }}$ August, 2018. London: The Economist.

The Economist (2019). 'The new scramble for Africa', The Economist, $7^{\text {th }}$ March 2019. London: The Economist.

EDFI (2011). Harmonized EDFI Exclusion List. Brussels: EDFI.

European Commission (2016). 10 Benefits of Economic Partnership Agreements. Brussels: European Commission.

European Commission (2019). Public Consultation on Revising the European Consensus on Development. Brussels: European Commission.

European Parliament (2016). European Parliament Resolution of 16 April 2016 on the Private Sector and Development. Brussels: European Parliament.

Fanon, F. (1961). The Wretched of the Earth. London: Penguin Classics.

Finch, R. and Crois, D. (2018). The EU and Africa: A Tale About Manipulation and Exploitation. EFDD: Brussels.

Global Justice Now (2020). An Open Letter to the UK Government on the UK-Africa Investment Summit. London: Global Justice Now.

Gruhn, I. (1976). 'The Lomé Convention: Inching towards interdependence', International Organization, 30(2): 241-62.

DOI: https://doi.org/10.1017/S0020818300018269

Hanssen, P. and S. Jonsson. (2014). Eurafrica: The Untold History of European Integration and Colonialism. London: Bloomsbury Academic.

Henokl, T. (2018). 'How Brexit affects EU external action: The UK's legacy in European international cooperation', Futures, 97: 63-72. https://doi.org/10.1016/j.futures.2017.07.002

Kohnert, D. (2018). 'Britain and Africa: Heading for the Brexit rocks', Africa Spectrum, 53(2): 1-22. DOI: 10.2139/ssrn.3235451

Krapohl, S. and Van Huut, S. (2019). 'A missed opportunity for regionalism: The disparate behaviour of African countries in the EPA negotiations with the EU', Journal of European Integration, early online version: 1-18. https://doi.org/10.1080/07036337.2019.1666117

Langan M and Scott J. (2014). 'The Aid for Trade charade', Cooperation and Conflict 49(2): $143-161$. https://doi.org/10.1177/0010836713482880

Langan, M. (2015). 'Budget support and Africa-European Union relations: Free market reform and neocolonialism?', European Journal of International Relations, 21(11): 101-121. https://doi.org/10.1177/1354066113516813

Langan M. (2016). 'Brexit and trade ties between Europe and Commonwealth states in sub-Saharan Africa: Opportunities for pro-poor growth or a further entrenchment of North-South inequalities?', The Round Table: The Commonwealth Journal of International Affairs 105 (5): 477-487. https://doi.org/10.1080/00358533.2016.1233758

Langan, M. (2018). Neo-Colonialism and the Poverty of 'Development' in Africa. New York: Palgrave.

Lightfoot, S.; Mawdsley, E. and Szent-Ivanyi, B. (2017). 'Brexit and UK International Development Policy', The Political Quarterly, 88(3): 517-524. https://doi.org/10.1111/1467-923X.12369

Mailafia, O. (1997). Europe and Economic Reform in Africa: Structural Adjustment and Economic Diplomacy. London: Routledge.

Martin, G. (1982). 'Africa and the ideology of Eurafrica: Neo-Colonialism or pan-Africanism?', Journal of Modern African Studies, 20(2): 221-238. 
Matambalya, F. S. (2009) 'Identifying products of defensive and offensive interests in both EPA trade regimes and WTO negotiations for commodity-dependent ACP economies: Lessons from an empirical review of Tanzania's agricultural sector', in Y. Ngangjoh-Hodu and F. S. Matambalya (Eds.) Trade Relations between the EU and Africa: Development, Challenges and Options Beyond the Cotonou Agreement. London: Routledge: $201-245$.

Mawdsley, E. (2015). 'DFID, the private sector, and the re-centring of an economic growth agenda in international development', Global Society, 29(3): 339-358. https://doi.org/10.1080/13600826.2015.1031092.

Mold, A. (2018). 'The Consequences of Brexit for Africa: The case of the East African Community', Journal of African Trade, 5, 1-17. https://doi.org/10.1016/j.joat.2018.10.001.

Monbiot, G. (2019). 'Why disaster capitalists are praying for a No Deal Brexit'. The Guardian, $7^{\text {th }}$ February. London: The Guardian.

Murray-Evans, P. (2016). 'Myths of Commonwealth betrayal: UK-Africa trade policy before and after Brexit', The Round Table: The Commonwealth Journal of International Affairs, 105: 489-498. https://doi.org/10.1080/00358533.2016.1233760.

Nkrumah, K. (1965). Neo-colonialism: The Last Stage of Imperialism. London: Nelson.

Pasture, P. (2018). 'The EC/EU between the art of forgetting and the palimpsest of empire', European Review, 26 (3): 545 581. https://doi.org/10.1017/S1062798718000224.

Price, S. (2016) 'Brexit, development aid, and the Commonwealth', The Round Table: The Commonwealth Journal of International Affairs, 105(5): 499-507. https://doi.org/10.1080/00358533.2016.1233762.

RIAO-RDC and GRAIN (2015). Agro-Colonialism in the Congo: European and US Development Finance Bankrolls a New Round of Agro-Colonialism in the DRC. Barcelona: GRAIN.

Sweeney, B. and Sydor, T. (2020). Brexit: Changing Rules on Asset Stripping for Private Equity Funds. London: Pricewaterhouse Coopers.

Thorpe, B. (2018). 'Eurafrica: A pan-European vehicle for Central European colonialism (1929-1939)' European Review, 26(3): 503-513. https://doi.org/10.1017/S1062798718000200.

Touré, S. (1962). 'Africa's Future and the World', Foreign Affairs, 41: 141-151.

Traidcraft (2017). Post-Brexit Trade. London: Traidcraft.

Saygili, M. and Peters, R. and Knebel, C. (2018). African Continental Free Trade Area Challenges and Opportunities of Tariff Reductions. New York: UNCTAD. 